\title{
Çocuk ve Adölesanlarda Şeker İlaveli İçeceklerin Tüketimi ve Sağlık Üzerine Etkileri
}

\section{Sugar Sweetened Beverages in Childrens and Adolescents and Their Effects on Health}

\author{
Mücahit Muslu ${ }^{1 *}$, Seda Kermen ${ }^{2}$ \\ ${ }^{1}$ İstanbul Arel Üniversitesi, Sağlık Bilimleri Yüksekokulu, Beslenme ve Diyetetik Bölümü \\ ${ }^{2}$ İstanbul Kültür Üniversitesi, Sağlık Bilimleri Fakültesi, Beslenme ve Diyetetik Bölümü \\ e-mail: dytmuslu@gmail.com, s.kermen@iku.edu.tr \\ ORCID; 0000-0002-8761-5061 \\ ORCID; 0000-0003-1650-0213 \\ *Sorumlu Yazar / Corresponding Author: Mücahit Muslu ${ }^{1}$ \\ Gönderim Tarihi / Received: 10.07.2019 \\ Kabul Tarihi / Accepted:08.05.2020 \\ DOI: $10.34087 /$ cbusbed.589831
}

\begin{abstract}
Çocuk ve adölesanlar tarafından sık tüketilen şeker ilaveli içecekler, yüksek enerji içeriğine sahip en geniş ilave şeker kaynağıdır. Meyve suları, gazlı içecekler, enerji içecekleri gibi içecekler bu gruba girmektedir. İçeriğinde bulunan şeker türleri, tatlandırıcılar, kafein, uyarıcı maddeler çocuk sağlığı açısından risk taşıyabilmektedir. Bu içeceklerin tüketimi cinsiyet, yaş, etnisite, sosyoekonomik durum, eğitim seviyesi gibi birçok faktörden etkilenmektedir. Kronik kullanımının fazla kilo, kalp damar problemleri, metabolik sendrom, Tip 2 diyabet, kan lipidlerinde ve kan basıncında artış gibi birçok hastalık ile ilişkili olabileceğini gösteren çalışmalar mevcuttur. Olumsuz sağlık etkileri çok küçük yaştan başlayarak yetişkinlik döneminde devam edebilmektedir. Bu nedenle çocuk sağlığı açısından erken dönemde bilimsel öneriler çerçevesinde çocuk, aile, çevre ve politikalar üzerinde çalışmalar yapılarak sağlıklı besin tüketimleri desteklenmelidir.
\end{abstract}

Anahtar Kelimeler: Şeker ilaveli içecek, içecek, ilave şeker, çocuk

\begin{abstract}
Sugar sweetened beverages, which are frequently consumed by children and adolescents, are the largest source of added sugar with a high energy content. Beverages such as fruit juices, sodas, energy drinks are in this group. Types of sugars, sweeteners, caffeine, stimulants present in the ingredients may be at risk for child health. Consumption of these beverages is affected by many factors such as gender, age, ethnicity, socioeconomic status, education level. There are studies showing that chronic use may be associated with many diseases such as overweight, cardiovascular problems, metabolic syndrome, Type 2 diabetes, increased blood lipids and blood pressure. Negative health effects can continue in adulthood, starting from very young age. For this reason, healthy food consumption should be supported by working on children, family, environment and policies within the framework of scientific proposals at the earliest stage in terms of child health.
\end{abstract}

Keyword: Sugar sweetened beverage, beverage, added sugar, child

\section{Giriş}

Şeker glukoz, galaktoz, fruktoz gibi monasakkarit veya maltoz, laktoz, sükroz, trehaloz gibi disakkaritleri tanımlamak için kullanılan bir kavramdır. Gıda sektöründe tatlandırmak, korumak veya kıvam kazandırmak gibi fonksiyonel amaçlarla kullanılmaktadır. Gıdaların doğal yapısında bulunan fruktoz, galaktoz gibi monosakkaritlerin dışında işlem ve hazırlama sırasında çeşitli amaçlarla dışarıdan eklenen şekere ise ilave şeker denilmektedir. Bal gibi doğal kaynaklar yanında beyaz şeker, kahverengi şeker, mısır şurubu gibi şuruplar, fruktoz türevleri genel olarak 
kullanılan ilave şekerlerdir. İlave şekerin diyetteki kaynakları kekler, bisküviler, tatlılar, şekerlemeler ve şeker ilaveli içecekler gibi ürünlerdir. $\mathrm{Bu}$ besinler genellikle yüksek enerji içerirken düşük besin değerine sahiplerdir [1]. İlave şeker alımı ile fazla kilo alımı ve bu nedenle Tip 2 diyabet, obezite, kalp hastalıkları gibi sağlık sorunları gözlenebilmektedir. İlave şeker alımının azaltılması bu hastalıklar ve komplikasyonlarına karşı koruyucu etki göstermektedir. Dünya Sağlık Örgütü ilave şeker için daha önce önerdiği toplam enerjinin \%10'unu aşmamalı önerisini, \%5 yapma yönünde tavsiye kararı vermiştir [2]. Amerikan G1da ve İlaç Dairesi (FDA) tarafından yapılan son öneriler arasında ilave şekerin gram cinsinden ve günlük yüzde olarak etikette gösterilmesi yer almaktadır [3]. Bu öneri ile ilave şeker alımının azaltılacağı düşünülmektedir [4].

İçecekler, çocukların yapacağı ilk bağımsız besin seçimleri arasında yer almaktadır. Sağlıksız seçimler, çocukların sağlığı için tehdit oluşturmaktadır. Yapılan bir çalışmada şeker içeriği, yapay tatlandırıcılar, kafein ve meyve içeriği ebeveynlerin ve çocukların içeceklere yönelik sağlı algılarının belirleyicileri olarak bulunmuştur. Çocuklar ve ebeveynleri arasındaki sağlık algısı benzer olmakla birlikte meyve içeriği çocuklar tarafından daha önemli bir etken olarak kabul edilmiştir [5]. Avrupalı çocuk ve adölesanlarda şeker tüketimi önerilerin üzerindedir. Tüketilen şekerin büyük bölümü şeker ilaveli içeceklerden gelmektedir. Bu durum çocuk sağlığı için risk oluşturmaktadır. Sağlık riskleri göz önüne alındığında çocuk ve adölesanlarda ilave şeker alımını azaltmaya yönelik ulusal politikalar hayata geçirilmesi gerekmektedir. Eğitim, ürün etiketlemenin geliştirilmesi, reklamların kısıtlanması ve okul yemeklerinin standartlaştırılması bu politikalar kapsamına dahil edilebilmektedir [6]. Yapılan bir çalışmaya göre bebeklik döneminde şeker ilaveli içecek tüketimi, 6 yaşındaki çocuklarda günde en az 1 porsiyon şeker ilaveli içecek tüketimi ile ilişkili bulunmuştur. $\mathrm{Bu}$ nedenle, tüketiminin azaltılmasına yönelik müdahalelerin en erken zamanda yapılması önerilmektedir [7]. Amerika'da bu konuda yapilan eğitimsel çalışmalar sonucunda 2000 yılına kadar gözlenen artışlar düşüş eğilimine geçmiştir. Buna rağmen hala tüketim önerilerin üstündedir [8].

\section{Şeker İlaveli İçecek Çeşitleri}

\section{Meyve Suyu}

FDA, bir ürünün meyve suyu olarak etiketlenebilmesi için \%100 meyve suyu içeriğine sahip olması şartını koşar. Daha az oranlarda içeren gıdalara 'içecek', 'nektar', 'kokteyl' gibi açıklayıcı maddeler konulmak zorundadır. Genel olarak meyve suyu içecekleri \%10-99 arasında meyve suyu, ilave tatlandırıcılar ve bazen $\mathrm{C}$ vitamini veya kalsiyum gibi güçlendiriciler içerir. $\mathrm{Bu}$ bileşenler, FDA yönetmeliklerine göre etiket üzerinde listelenmektedir [9]. Türk G1da Kodeksi Tebliği'ne göre '\%100 meyve suyu' ifadesi meyve suyu ve konsantreden üretilen meyve suyu etiketlerinde kullanılmaktadır [10].
Su, meyve suyunun baskın bileşenidir. Sakkaroz, fruktoz, glukoz ve sorbitol meyve suyunda bulunan bir sonraki en yaygın besin öğeleridir. Karbonhidrat konsantrasyonu 11 gr'dan $(0,44 \mathrm{kcal} / \mathrm{ml}) 16$ gr'a $(0,64$ $\mathrm{kcal} / \mathrm{ml}$ ) kadar değişis. Süt ve standart bebek formüllerinin karbonhidrat konsantrasyonu ise $\% 7 \mathrm{gr}$ 'dır. Bazı meyve sularında doğal olarak yüksek miktarda potasyum, A vitamini ve $\mathrm{C}$ vitamini içeriği bulunur. Meyve hamuru içermezse lif oranı çok düşüktür [9].

\section{Gazlı İçecekler}

Karbondioksit ile gazlandırılmış olan meyveli, aromalı, gazoz gibi içecekler şeklinde tanımlanmaktadır. Gazlı içecekler asit ve bikarbonat içermektedir [11]. Türk Gıda Kodeksi'nde gazlı meyveli ve meyveli doğal mineralli içeceklerde meyve oranının ağırlıç̧a en az \%4 olması gerektiği belirtilmektedir. Ayrıca, bu tebliğe göre ürün etiketinde 'gazlı' ifadesi yer almalıdır [12]. Bu içeceklerin tüketilmesi obezite, diyabet, diş çürükleri, karaciğer sirozu gibi birçok hastalıkla ilişkilendirilmiştir [11]. Çocuk sağlığına olumsuz etkilerinden ötürü ABD gibi bazı ülkelerde okul içinde satışı yasaklanmıştır [13].

\section{Enerji İçecekleri}

Enerji içecekleri içeriğindeki yoğun karbonhidrat nedeni ile enerji sağlayan, belirli limitlerde fonksiyonel madde, vitamin ve mineraller içerebilen içecekler olarak tanımlanmıştır [14]. $\mathrm{Bu}$ içecekler kafein, taurin, metilksantin, gingseng, guarana, yerbamate, açai, maltodekstrin, inositol, karnitine, kreatine, glukuronolaktone, ginkgobiloba, tatlandırıcılar ve yüksek oranda şeker içermektedir [15]. İlk kez ABD'de üretimi yapılmıştır. Enerji içeceklerinin enerji sağlayarak performans arttırdı ğı, yorgunluğu azalttığı ve dikkati arttırdığı gibi söylemler ile özellikle gençler arasında tüketimi hızla yaygınlaşmıştır [16-18]. Ancak yapılan çalışmalar neticesinde terapötik etkisinin olmadığı, farmakolojik etkiler ve toksisitesinden ötürü özellikle çocuklarda ciddi sorunlara neden olabileceği bildirilmiştir [19]. Avrupa'da 1987 yılında piyasaya girerek 1997 yılında enerji içeceği üreten firmaların tanıtımları ile birçok ülkeye yayılmıştır [20]. Bu ürünler USDA ve FDA tarafından onaylanmamıştır [21]. Bazı ülkelerde kısıtlamalar getirilirken bazılarında da 18 yaş altına satışı yasaklanmıştır [22]. Ülkemizde ürün içeriklerinin asgari ve azami limitleri belirlenerek yaş kısıtlaması olmadan satışı yapılmaktadır [14]. Ek olarak, yapılan bir çalışmada üniversite öğrencilerinin \%55'inin enerji içeceği tükettiği ve \%73'ünün bu içecekler hakkında bilgiye sahip olmadığı saptanmıştır [23].

\section{Şeker İlaveli İçeceklerin İçerikleri}

\section{Fruktoz ve Yüksek Fruktozlu Misır Şurubu}

Fruktoz doğal olarak meyve ve balda bulunan bir monosakkarittir. Günümüzde sükroz ve yüksek fruktozlu misır şurubu temel kaynağı teşkil etmektedir. Son yıllarda ilave şeker tüketiminin artması ile günlük fruktoz tüketimi 60-150 gr değerlerine ulaşmıştır [24]. 
Sükroza alternatif olarak 1920'lerde yüksek fruktozlu mısır şurubu (HFCS) üretilmiş ve 1970'li yıllarda ABD'de diyette geniş yer kaplamıştır. Glikoamilaz ve aamilaz ile hidrolizasyon sonucu elde edilir. Fruktoz içeriğine göre farklı türleri bulunmaktadır [25]. Şekerli içeceklerde daha çok \%1-3 polisakkarid, \%42-44 glukoz, $\% 55$ fruktoz içeren HFCS-55 kullanılmaktadır [26]. HFCS-42 ise çorba, unlu mamüller gibi paketli ürünlerde tercih edilmektedir. Ticari olarak daha ucuz ve gida üretim aşamalarında kullanışlı olduğundan sükroza göre daha çok tercih edilmektedir [27].

Fruktozun emilimi ve metabolizması glukozunkinden farklıdır. Daha lipojenik etkiye sahip olması ve leptin bağımsız olması nedeni ile hastalıklar için risk oluşturmaktadır [28]. Yüksek fruktoz alımı insülin direnci, inflamasyon, yüksek kan basınc1, karaciğer yağlanması, obezite, endotel disfonksiyon, hiperürisemi, gut, böbrek hasarı gibi birçok hastalıkla ilişkili bulunmuştur [29]. Fruktoz, glukoz olmasa bile aynı hızda substrat etki göstererek bazı kanser türlerinin gelişmesinde etkili olmaktadır [30]. Yedi prospektif kohort çalışmasının incelendiği bir meta-analizde pankreas kanseri ile artmıș fruktoz alımı arasında pozitif bir ilişki bulunmuştur [31]. Yapılan bir çalışmada yüksek fruktozun diğer şeker türlerine göre reaktif oksijen üretiminin daha fazla arttırdığı belirtilmiştir [32]. Ayrıca, DNA metilasyonunu değiştirerek metabolik farklılıklara neden olduğu da ileri sürülmüştür [33].

\section{Tatlandirlcilar}

Tatlandırıcılar düşük yoğunlukta enerji içeren veya hiç içermeyen, sükroza göre daha tatlı olan kimyasal maddelerdir. Düşük maliyet ve yüksek tat nedeni ile gıda sanayisinde uzun süredir kullanılmaktadır. Enerji içermeyen türleri diyabet, obezite, diş çürükleri gibi hastalıklardan korunmak amacı ile kullanılmaktadır. Tatlandırıcılar şeker alkolleri, doğal ve yapay tatlandırıcılar olmak üzere üç grupta sınıflandırılır. Şeker alkolleri; hidrojene nişasta hidrolizatları, sorbitol, mannitol, ksilitol, laktilol, eritritol, maltilol ve isomalttır. Fonksiyonel olarak alkollere benzeyen trehaloz ve tagatozda bu grupta incelenir. Doğal tatlandırıcılar; stevia, bal, akçaağaç şurubu gibi maddelerdir. FDA tarafından onaylanmış yapay tatlandırıcılar ise sakkarin, aspartam, sukraloz, asesulfam K ve neotamdır. Siklamat ve alitam da birçok ülkede kullanılmaktadır [34]. İdeal tatlandırıcılar sükroza oranla daha tatlı, renksiz, kokusuz, suda çözülebilen, farklı ısılarda stabil kalabilen, kalıcı tat bırakmayan aynı zamanda karsinojenik veya toksik etki yapmayacak, normal olarak metabolize edilebilecek ve değişmeden vücuttan atılabilecek şekilde olmalıdır [35]. Tatlandırıcılar için FDA tarafından kabul edilebilir günlük alım değerleri belirlenmiş ve bu oranların güvenli olacağı belirtmiştir [36]. Diyetle yaşam boyu kilo başına günlük alımı, herhangi bir riske neden olmayan madde miktarı "kabul edilebilir günlük alım (ADI)", şeklinde tanımlanmıştır [37]. Tatlandırıcılar için bu değerler; Stevia 4, Asesulfam K 15, Sukraloz 5-15, Aspartam 50, Sakkarin 5 mg/kg/gün iken Neotam 18 mg/gün'dür [36].

\section{Kafein}

Günlük 100-400 mg kafein tüketimi ile çocuk ve adölesanlarda sinirlilik, huzursuzluk, tedirginlik ve harekette artış gözlemlenmiştir. ABD'de kafein tüketimi 60-800 mg/gün arasında değişmektedir. Yetişkinlerde asıl kaynak kahve iken çocuk ve adölesanlarda gazlı içeceklerdir [38,39]. Kafein, enerji içeceklerinde de yüksek miktarda bulunan etkili maddelerdendir [40]. Türk Gıda Kodeksi'ne göre bir enerji içeceğinde bulunan toplam kafein miktarı $150 \mathrm{mg} / \mathrm{L}$ 'yi aşmamalıdır [41]. Adölesanlarda kafein daha çok gazlı içeceklerden alınırken, enerji içecekleri ile alım da artış göstermektedir. Bu içeceklerin tüketimi yüksek BKİ ve buna bağlı sorunların yanı sıra sebze, meyve ve süt tüketiminin azalması ile ilişkili bulunmuştur [42].

\section{Şeker İlaveli İçeceklerin Tüketim Sıklıkları}

Geçtiğimiz on yıl boyunca şeker ilaveli içecek tüketimi çoğu ülkede önemli ölçüde artarken, bazı ülkelerde ise 2000 yıllarında başlayan bazı düşüşler gözlenmiştir [43]. Örneğin, ABD'de 2003-2014 yıllarında yapılan çalışmada hem yetişkinler hem de çocuklarda şeker ilaveli içecek tüketimi azalma göstermiștir. Şekerli içeceklerden gelen kaloriler çocuklar için 224,6 kaloriden 132,5 kaloriye ve yetişkinler için 190,4 kaloriden 137,6 kaloriye gerilemiştir [44]. Suudi Arabistan'da 7-12 yaş arası 725 çocuğun katıldığı bir çalışmada gazlı içecek tüketim sıklığı günlük \%17,1 iken haftalık \%53,3 bulunmuştur. Ayrıca, bu çalışmada yaş ve tüketim arasında pozitif ilişkili bulunmuştur [45]. Yapılan başka bir çalışmada ise $(n=4283)$ katılımcıların \%62'sinin şeker ilaveli içecek kullandığı bildirilmiştir. Aynı çalışmada yaşı büyük ve ekonomik durumu düşük olan çocukların şeker ilaveli içeceklerin tüketiminde daha 1srarcı oldukları belirtilmiştir [46]. Çin'de 6-13 yaş arası 6974 çocuk üzerinde yapılan çalışmada düzenli şeker ilaveli içecek tüketim sıklığ $\% 46,1$ olarak bulunmuştur. Ayrıca obezite ve abdominal obezite ile pozitif ilişkili bulunmuş [47].

\section{Şeker İlaveli İçecek Tüketimini Etkileyen Faktörler}

Çok yaygın bir obezojenik davranış olan şeker ilaveli içeceklerin tüketimi çeşitli faktörlerden etkilenmektedir. ABD'de 3-18 yaş arası 717 erkek ve 686 kız katılımcı ile yürütülen çalışmada şeker ilaveli içecek tüketiminin ırk, yaş, cinsiyet gibi sosyodemografik özelliklerden etkilenmektedir. Bu içeceklerin tüketimi 8-12 yaş arası çocuklarda 3-5 yaş arası çocuklara göre daha yüksek bulunmuştur. Özellikle ebeveynlerin yüksek düzey şeker ilaveli içecek tüketimi çocuklarda tüketimi arttıran bir diğer faktördür. Ayrıca, yüksek eğitim seviyesine sahip ebeveyn ve düzenli kahvaltı yapma alışkanlığı ile şeker ilaveli içeceklerin tüketiminin ters ilişkili görülmüştür [48]. Benzer şekilde yüksek eğitim seviyesine sahip annelerin çocuklarında, orta eğitim seviyeli annelerin çocuklarına göre şeker ilaveli içeceklerin tüketimi daha düşük bulunmuştur. Anne eğitim düzeyi ile çocukların tüketimi arasındaki ilişkiye, ebeveynlerin atıştırmalık ve şeker ilaveli içecek tüketimi ile bu içeceklerin evde bulunabilirliğinin aracılık ettiği saptanmıştır. Ev ortamı, 
çocukların besin tercihlerinin şekillenmesinde ve gelişmesinde önemli bir konumdadır [49]. Adölesanların (12-17 yaş) katıldığ 1 ulusal bir araştırmada reklam duyarlılığı şekerli içecek tercihi ve tüketiminin güvenilir bir belirleyicisi olarak bulunmuştur [50]. Şekerli içecek tüketimi aile, çevre ve okul politikası ile yakın ilişkilidir. Çocuklarda şeker ilaveli içeceklerin tüketimini etkileyen faktörlerin belirlenmesi, bu içeceklerin tüketimini azaltmak için etkili müdahalelerin yapılmasına olanak sağlar. Etkili bir müdahale ebeveyn, çocuk ve çevre düzeyindeki belirleyicileri birlikte içermelidir [51].

\section{Şeker İlaveli İçeceklerin Tüketimi ve Sağlık İlişkisi}

\section{Mikrobiyal Etki}

Pastörize edilmemiş meyve suyu ürünleri Escherichia coli, Salmonella türleri ve Cryptosporidium türleri gibi çocuklar ve bebekler için zararlı olabilecek patojenleri içerebilir. Bu organizmalar hemolitik sendrom gibi ciddi hastalıklarla ilişkilendirilir. Aileler, pastörize edilmemiş meyve suyu ürünlerini temin ederken bilinçli olmalıdır. Pastörize meyve suları mikroorganizma içermez. Bebekler, çocuklar ve ergenler için mikrobiyal açıdan güvenlidir $[52,53]$.

\section{Alerji}

Portakal suyuna maruz kalan bebekler için, alerji geliştirme olasılığının artması bir endişe konusudur. Yeni s1kılan narenciye suyunun tüketiminden sonra bazı bebeklerde perioral bir döküntü oluşması asidin kimyasal tahriş edici etkilerinden kaynaklanabilir. Bazı bebeklerde görülen ishal ve diğer gastrointestinal belirtiler büyük olasılıkla karbonhidrat malabsorpsiyonuna bağlanabilir. Her ne kadar meyve alerjisi yaşamın erken dönemlerinde gelişebilirse de nadirdir [9]. Çocuklarda ve ergenlerde aşırı serbest fruktoz içecek alımı ile alerjik semptomlar ve alerjik duyarlılık arasında bir bağlantı olabileceği öne sürülmektedir [54].

\section{Obezite}

Obezite artışına paralel olarak ortaya çıkan şeker ilaveli içecek tüketiminin artması, bu içeceklerin nedensel bir rol oynayabileceği endişesini uyandırmıştır. Yapılan sistemik bir derlemede bir randomize kontrollü ve 37 kohort çalışması incelenmiştir. Bu çalışmanın sonucunda 12 yaşın altındaki çocuklarda şeker ilaveli içecek tüketimi ile total adipozite ve santral adipozite arasında anlamlı pozitif bir ilişki olduğu gösterilmiştir [55]. Tayvan'da 12-16 yaş arası 1454 çocuk arasında yapılan bir çalışmada fruktoz açısından zengin şeker ilaveli içecek alımı ile bel çevresinde artış ilişkilendirilmiştir [56]. Başka bir çalışmada, yüksek şeker ilaveli içecek tüketimi ( $>4$ porsiyon/hafta) ile obezite arasında pozitif ilişki bulunmuştur. Tüketimin günlük bir porsiyon arttırılması obezitede \%69 artışa neden olmuştur. Bu etki çocuk ve ergenlerde doz yanıt ilişkisi ile çizgisel artış göstermiştir [57].

ABD'de Beslenme ve Diyetetik Akademisi Kanita Dayalı Analiz Kütüphanesi adına bir çalışma grubu tarafindan yapılan bir analiz de dahil olmak üzere (2-18 yaş arasında) literatürdeki iki yakın tarihli inceleme kanıtların çoğunun \%100 meyve suyu tüketimi ile çocuklarda kilo durumu veya yağlanma arasındaki ilişkiyi desteklemediği sonucuna varmıştır [58,59].

Anne ve çocukları ile yapılan prospektif doğum öncesi kohort çalışması sonuçlarına göre gebelik döneminde tüketilen şeker ilaveli içecekler ve çocukların ilerleyen dönemlerde yağlanma oranları arasında ilişki bulunmuştur. Doğum öncesi de dahil olmak üzere gelişimin en erken aşamalarını içeren önleme stratejileri, yaşam boyu obezite ve bulaşıcı olmayan hastalıkların önlenmesi için önem arz etmektedir [60]. Çocukluk dönemine (2-6 yaş) yönelik bir müdahale çalışmasında ise $100 \mathrm{gr} / \mathrm{gün}$ şeker ilaveli içecekler yerine $100 \mathrm{gr} / \mathrm{gün}$ süt idame edildiğinde vücut ağırlığı ve BMI-Z skorlarında düşüş yaşandığı belirtilmiştir [61].

\section{Tip 2 Diyabet}

Ateroskleroza neden olan ve erişkinlikte diyabet ve kardiyovasküler hastalık gelişme riskini artıran insülin direnci çocukluk döneminde ortaya çıkabilir ve yetişkinlik döneminde de devam edebilir. Yapılan bir çalışmaya göre daha fazla miktarda şekerli içecek tüketen adölesanların yüksek açlık serum insülini, HOMA1-IR ve HOMA2-IR'ye sahip olma olasılıkları daha yüksek bulunmuştur [56]. Bir meta-analiz çalışmasında 17 kohort çalışması incelenmiş, düzenli şeker ilaveli içeceklerin tüketiminin, adipoziteden bağımsız olarak Tip 2 diyabet insidansı ile ilişkili olduğu gösterilmiştir. Yıllar içinde şeker ilaveli içeceklerin tüketimi çok sayıda yeni başlayan diyabet vakasıyla ilişkili olabilir [62].

\section{Kardiyovasküler Hastalıklar}

Dislipidemi ile ilişkili aterosklerotik değişikliklerin ve buna bağlı artmış kardiyovasküler hastalık riskinin çocukluk çağında başladığı düşünülmektedir. Bir çalışmada düşük ilave şeker alımının yüksek HDL kolesterol seviyesi ile ilişkili olduğu gösterilmiştir [63]. Farklı bir çalışmada ilave şeker artışı yüksek trigliserid seviyesi ve yüksek kan basıncı ile ilişkili bulunmuştur [64]. Yapılan geniş çaplı bir meta analiz çalışmasında ise şeker ilaveli içecek tüketiminin yüksek hipertansiyon ve koroner kalp hastalıkları riski ile pozitif ilişkili olduğu saptanırken, inme riski ile ilişki saptanmamıştır [65]. Tip 1 diyabetli 2286 adölesanın katıldığı bir çalışmada iki günde bir şeker ilaveli içecek tüketenlerde, iki haftada bir tüketenlere göre daha yüksek total kolesterol ve LDL kolesterol konsantrasyonları bulunmuştur [66].

\section{Sonuç ve Öneriler}

Şeker ilaveli içecekler yüksek kalori ve düşük besin değeri içeren maddelerdir. Bu ürünlerin fazla tüketimi günlük ilave şeker alımını arttırmaktadır. Dünya Sağlık Örgütü günlük ilave şeker alımının günlük enerjinin \%5'ini geçmemesini önermiştir. Şeker ilaveli içeceklerin bir porsiyonu bile bu sınırı aşmaktadır. Kronik tüketime bağlı olarak diyabet, obezite ve kalp sağlı̆̆1 sorunları gibi birçok sağlık problemine neden olmaktadır. Bu nedenle ilave şeker içeren içeceklerin tüketiminin sınırlandırılması gerekmektedir. Bu içeceklerin özellikle 
beslenme alışkanlıklarının oluştuğu bebeklik ve çocukluk çağından itibaren kullanımına dikkat edilmelidir. Bebek ve çocuk beslenmesinde yeterli ve dengeli beslenme içinde bu ürünlerin gerekliliğinin bulunmadığı bilinmelidir. Ayrıca, adölesan dönemde tüketimi artan enerji içeceklerinin yüksek kalori dışında uyarıcı maddelerin yoğunluğu nedeni ile sağlığa olumsuz etkileri olabilmektedir. Tüm bu nedenler göz önüne alındığında bebeklik döneminden itibaren sağlıklı içecek tercihleri yapılmalı ve şeker ilaveli içecek tüketimi Dünya Sağlık Örgütü'nün belirlediği limitin üzerine çıkmamalıdır. Konunun daha detaylı aydınlatılabilmesi için daha geniş klinik kontrollü çalışmalara ihtiyaç vardır.

\section{Refereanslar:}

1. Otten, J.J, Hellwig, J.P, Meyers, L.D, Dietary reference intakes: the essential guide to nutrient requirements, National Academies Press, 2006.

2. World Health Organization, Guideline: sugars intake for adults and children, Geneva, 2015.

3. Food and Drug Administration, Food labeling: revision of the nutrition and supplement facts labels. Final rule, Federal Register, 2016, 81[103], 33741.

4. Drewnowski, A, Rehm, C.D, Consumption of added sugars among US children and adults by food purchase location and food source, The American Journal of Clinical Nutrition, 2014, 100[3], 901-7.

5. Bucher, T, Siegrist, M, Children's and parents' health perception of different soft drinks, British Journal of Nutrition, 2015, 113[3], 52635 .

6. Mis, N.F, Braegger, C, Bronsky, J, Campoy, C, Domellöf, M, Embleton, N.D, et al. Sugar in infants, children and adolescents: a position paper of the European Society for Paediatric Gastroenterology, Hepatology and Nutrition Committee on Nutrition, Journal of Pediatric Gastroenterology and Nutrition, 2017, 65[6], 681-96

7. Park, S, Pan, L, Sherry, B, Li, R, The association of sugar-sweetened beverage intake during infancy with sugar-sweetened beverage intake at 6 years of age, Pediatrics, 2014, 134[Supplement 1], S56S62.

8. Powel, E.S, Smith-Taillie, L.P, Popkin, B.M, Added sugars intake across the distribution of US children and adult consumers: 1977 2012, Journal of the Academy of Nutrition and Dietetics, 2016 116[10], 1543-50.

9. Heyman, M.B, Abrams, S.A, Fruit juice in infants, children, and adolescents: current recommendations, Pediatrics, 2017, e20170967.

10. Türk Gıda Kodeksi Meyve Suyu ve Benzeri Ürünler Tebliği, Tebliğ no:2014/34.

http://www.mevzuat.gov.tr/Metin.Aspx?MevzuatKod=9.5.19949\& Mevzuatlliski=0\&sourceXmlSearch=meyve\%20suyu [Erişim tarihi: 08.06.2019].

11. Gözener, B, Sayılı, M, Ankara İli Merkez İlçede Bireylerin Gazlı İçecek Tüketimine İlişskin Bir Değerlendirme, Türk Tarım-Gıda Bilim ve Teknoloji Dergisi, 2015, 3[6], 453-8.

12. Türk Gıda Kodeksi Alkolsüz İçecekler Tebliği. Tebliğ no: 2007/26. http://www.resmigazete.gov.tr/eskiler/2007/06/20070615-5.htm [Erişim tarihi: 08.06.2019].

13. Kaya, T, Ülengin, B, Tüketici paneli verisine dayalı bir marka tercih modeli: Türkiye gazlı meşrubatlar sektöründe bir uygulama, ITU Journal Series D: Engineering, 2009, 8[4].

14. Dikici, S, Aydin, L.Y, Kutlucan, A, Ercan, N, Enerji içecekleri hakkında neler biliyoruz? Dicle Tip Dergisi, 2012, 39[4], 609.

15. Aranda, M, Morlock, G, Simultaneous determination of riboflavin, pyridoxine, nicotinamide, caffeine and taurine in energy drinks by planar chromatography-multiple detection with confirmation by electrospray ionization mass spectrometry, Journal of Chromatography A, 2006, 1131[1-2], 253-60.

16. Reissig, C.J, Strain, E.C, Griffiths, R.R, Caffeinated energy drinksa growing problem, Drug and Alcohol Dependence, 2009, 99[1], 110 .
17. Howard, M.A, Marczinski C.A, Acute effects of a glucose energy drink on behavioral control, Experimental and Clinical Psychopharmacology, 2010, 18[6], 553.

18. Mets, M.A, Ketzer, S, Blom, C, Van Gerven, M.H, Van Willigenburg, G.M, Olivier, B, et al, Positive effects of Red Bull ${ }^{\circledR}$ energy drink on driving performance during prolonged driving, Psychopharmacology, 2011, 214[3], 737-45.

19. Thomson, B.M, Campbell, D.M, Cressey, P, Egan, U, Horn, B, Energy drink consumption and impact on caffeine risk, Food Additives and Contaminants: Part A, 2014, 31[9], 1476-88

20. Zucconi, S, Volpato, C, Adinolfi, F, Gandini, E, Gentile, E, Loi, A, et al, Gathering consumption data on specific consumer groups of energy drinks, EFSA Supporting Publications, 2013;10[3].

21. Arpac1, N, Ersoy, G, What is the power of energy drinks? Journal of Human Sciences, 2011, 8[1], 809-19.

22. Für Risikobewertung B, New human data on the assessment of energy drinks, Federal Institute for Risk Assessment, 2008.

23. Kayapınar, F.Ç, Özdemir, İ, Öğrencilerin enerji içeceği tüketim bilincinin ve alışkanlıklarının araştırılmasında bir meslek yüksekokulu örneği, Ankara Sağllk Hizmetleri Dergisi, 2016, 15[1], 1-12.

24. Arslan, S, Şanlıer, N, Fruktoz ve sağlık, Mersin Universitesi Saglık Bilimleri Dergisi, 2016, [9]:3.

25. Goran, M.I, Ulijaszek, S.J, Ventura, E.E, High fructose corn syrup and diabetes prevalence: a global perspective, Global Public Health, 2013, 8[1], 55-64.

26. Forshee, R.A, Storey, M.L, Allison, D.B, Glinsmann, W.H, Hein, GL, Lineback, D.R, et al, A critical examination of the evidence relating high fructose corn syrup and weight gain, Critical Reviews in Food Science and Nutrition, 2007, 47[6], 561-82.

27. Neilson, EG, The fructose nation, Journal of the American Society of Nephrology, 2007, 18[10], 2619-21.

28. Keim, N.L, Stanhope, K.L, Havel, P.J, Fructose and high-fructose corn syrup, In: Caballero B, Finglas P, Toldrá, F (eds), Encyclopedia of food and health, Academic Press, United Kingdom, 2016, pp 119124.

29. Charrez, B, Qiao, L, Hebbard, L, The role of fructose in metabolism and cancer, Hormone Molecular Biology and Clinical Investigation, 2015, 22[2], 79-89.

30. Liu, H, Heaney, A.P, Refined fructose and cancer. Expert Opinion On Therapeutic Target,. 2011, 15[9], 1049-59.

31. Aune, D, Chan, D, Vieira, A, Navarro Rosenblatt, D, Vieira, R, Greenwood, D, et al. Dietary fructose, carbohydrates, glycemic indices and pancreatic cancer risk: a systematic review and metaanalysis of cohort studies, Annals of Oncology, 2012, 23[10], 253646.

32. Mattioli, LF, Holloway, N.B, Thomas, J.H, Wood, J.G, Fructose, but not dextrose, induces leukocyte adherence to the mesenteric venule of the rat by oxidative stress, Pediatric Research, 2010, 67[4], 352.

33. Yamazaki, M, Munetsuna, E, Yamada, H, Ando, Y, Mizuno, G, Murase, Y, et al, Fructose consumption induces hypomethylation of hepatic mitochondrial DNA in rats, Life Sciences, 2016, 149, 146-52.

34. Özdemir, D, Başer, H, Çakır, B, Tatlandırıcılar, Türkiye Klinikleri Journal of Endocrinology, 2014, 9[2], 60-70.

35. Nabors, L, Gelardi, R, Alternative sweeteners: an overview, Alternative Sweeteners, 2001, 2:1-10.

36. Kroger, M, Meister, K, Kava, R, Low-calorie sweeteners and other sugar substitutes: a review of the safety issues, Comprehensive Reviews in Food Science and Food Safety, 2006, 5[2], 35-47.

37. Chattopadhyay, S, Raychaudhuri, U, Chakraborty, R, Artificial sweeteners-a review, Journal of Food Science and Technology, 2014, 51[4], 611-21.

38. Temple, J.L, Caffeine use in children: what we know, what we have left to learn, and why we should worry, Neuroscience and Biobehavioral Reviews, 2009, 33[6], 793-806.

39. Pollak, C.P, Bright, D, Caffeine consumption and weekly sleep patterns in US seventh-, eighth-, and ninth-graders, Pediatrics, 2003, $111[1], 42-6$

40. Pennay, A.E, Lubman, D.I, Energy drinks: health risks and toxicity, The Medical Journal of Australia, 2012, 196[7], 442.

41. Türk Gıda Kodeksi Enerji İçecekleri Tebliği. Tebliğ no: 2017/4. http://www.resmigazete.gov.tr/eskiler/2017/06/20170930-23.htm [Erişim tarihi: 08.06.2019].

42. Temple, J.L, Dewey, A.M, Briatico, L.N, Effects of acute caffeine administration on adolescents, Experimental and Clinical Psychopharmacology, 2010, 18[6], 510. 
43. von Philipsborn, P, Stratil, J.M, Burns, J, Busert, L.K, Pfadenhauer, L.M, Polus, S, et al, Environmental interventions to reduce the consumption of sugar-sweetened beverages and their effects on health, Cochrane Database of Systematic Reviews, 2019, [6], CD012292.

44. Bleich, S.N, Vercammen, K.A, Koma, J.W, Li, Z, Trends in beverage consumption among children and adult, 2003-2014, Obesity, 2018, 26[2], 432-41.

45. Alsubaie, A.S.R, Consumption and correlates of sweet foods, carbonated beverages, and energy drinks among primary schoo children in Saudi Arabia, Saudi Medical Journal, 2017, 38[10], 1045.

46. Grimes, C.A, Riddell, L.J, Campbell, K.J, Nowson, C.A, Dietary sal intake, sugar-sweetened beverage consumption, and obesity risk, Pediatrics, 2013, 131[1], 14-21.

47. Shang, X.W, L1u, A.L, Zhang, Q, Hu, XQ, Du, SM, Jun, M, et al, Report on childhood obesity in China: sugar-sweetened beverages consumption and obesity, Biomedical and Environmental Sciences, 2012, 25[2], 125-32.

48. Tasevska, N, DeLia, D, Lorts, C, Yedidia, M, Ohri-Vachaspati, P, Determinants of sugar-sweetened beverage consumption among lowincome children: are there differences by race/ethnicity, age, and sex? Journal of the Academy of Nutrition and Dietetics, 2017, 117[12], 1900-20.

49. van Ansem, W.J, van Lenthe, F.J, Schrijvers, C.T, Rodenburg, G, van de Mheen, D, Socio-economic inequalities in children's snack consumption and sugar-sweetened beverage consumption: the contribution of home environmental factors, British Journal of Nutrition, 2014, 112[3], 467-76.

50. Gesualdo, N, Yanovitzky, I, Advertising susceptibility and youth preference for and consumption of sugar-sweetened beverages: findings from a national survey, Journal of Nutrition Education and Behavior, 2019, 51[1], 16-22.

51. Mazarello Paes, V, Hesketh, K, O'Malley, C, Moore, H, Summerbell, $\mathrm{C}$, Griffin, S, et al, Determinants of sugar-sweetened beverage consumption in young children: a systematic review, Obesity Reviews, 2015, 16[11], 903-13.

52. Noël, H, Hofhuis, A, De Jonge, R, Heuvelink, A.E, De Jong, A, Heck, M.E, et al, Consumption of fresh fruit juice: how a healthy food practice caused a national outbreak of Salmonella Panama gastroenteritis. Foodborne Pathogens and Disease, 2010, 7[4], 375 81.

53. Jain, S, Bidol, SA, Austin, JL, Berl, E, Elson, F, Williams, M.L, et al, Multistate outbreak of Salmonella Typhimurium and Saintpau infections associated with unpasteurized orange juice - United States 2005, Clinical Infectious Diseases, 2009, 48[8], 1065-71.

54. Yu, R, Yang, B, Cai, L, Lu, X, Wang, X, Excess free fructose beverages and allergy in children and adolescents: Results from NHANES 2005-2006, The Annals of Family Medicine, 2018, 16[5], 408-418.

55. Frantsve-Hawley, J, Bader, JD, Welsh, JA, Wright, J.T, A systematic review of the association between consumption of sugar-containing beverages and excess weight gain among children under age 12, Journal of Public Health Dentistry, 2017, 77[S1].

56. Lin, W-T, Chan, T-F, Huang, H-L, Lee, C-Y, Tsai, S, Wu, P-W, et al, Fructose-rich beverage intake and central adiposity, uric acid, and pediatric insulin resistance, The Journal of Pediatrics, 2016, 171, 90-

57. Martin-Calvo, N, Martínez-González, M-A, Bes-Rastrollo, M, Gea A, Ochoa, M.C, Marti, A, Sugar-sweetened carbonated beverage consumption and childhood/adolescent obesity: a case-control study, Public Health Nutrition, 2014, 17[10], 2185-93.

58. Rampersaud, G.C, 100\% Fruit juice: perspectives amid the sugar debate, Public Health Nutrition, 2016, 19[5], 906-13.

59. O'Neil, C.E, Nicklas, T.A, Childhood obesity and the consumption of $100 \%$ fruit juice: where are the evidence-based findings? Fructose high fructose corn syrup, sucrose and health: Springer; 2014. p. $247-$ 75

60. Gillman, M.W, Rifas-Shiman, S.L, Fernandez-Barres, S, Kleinman, $\mathrm{K}$, Taveras, E.M, Oken, E, Beverage intake during pregnancy and childhood adiposity, Pediatrics, 2017, e20170031.

61. Zheng, M, Rangan, A, Allman-Farinelli, M, Rohde, J.F, Olsen, N.J, Heitmann, B.L, Replacing sugary drinks with milk is inversely associated with weight gain among young obesity-predisposed children, British Journal of Nutrition, 2015, 114[9], 1448-55.

62. Imamura, F, O'Connor, L, Ye, Z, Mursu, J, Hayashino, Y, Bhupathiraju, S.N, et al, Consumption of sugar sweetened beverages, artificially sweetened beverages, and fruit juice and incidence of type 2 diabetes: systematic review, meta-analysis, and estimation of population attributable fraction, British Medical Journal, 2015, 351, h3576.

63. Lee, AK, Binongo, J.N.G, Chowdhury, R, Stein, A.D, Gazmararian, J.A, Vos, M.B, et al, Consumption of less than $10 \%$ of total energy from added sugars is associated with increasing HDL in females during adolescence: a longitudinal analysis, Journal of the American Heart Association, 2014, 3[1], e000615.

64. Kell, K.P, Cardel, M.I, Bohan Brown, M.M, Fernández, J.R, Added sugars in the diet are positively associated with diastolic blood pressure and triglycerides in children, The American Journal of Clinical Nutrition, 2014, 100[1], 46-52.

65. Xi, B, Huang, Y, Reilly, K.H, Li, S, Zheng, R, Barrio-Lopez, M.T, et al, Sugar-sweetened beverages and risk of hypertension and CVD: a dose-response meta-analysis, British Journal of Nutrition, 2015 113 [5], 709-17.

66. Liese, A.D, Crandell, J.L, Tooze, J.A, Kipnis, V, Bell, R, Couch, S.C, et al, Sugar-sweetened beverage intake and cardiovascular risk factor profile in youth with type 1 diabetes: application of measurement error methodology in the SEARCH Nutrition Ancillary Study, British Journal of Nutrition, 2015, 114[3], 430-8.

http://edergi.cbu.edu.tr/ojs/index.php/cbusbed isimli yazarın CBU-SBED başlıklı eseri bu Creative Commons Alınt1-Gayriticari4.0 Uluslararas1 Lisans1 ile lisanslanmıștır. 